\title{
Writers in uniform
}

In our search for reflections of aesthetic response to the Great War across barriers of experience, the soldier, poet and author Richard Aldington is a good example of John Galsworthy's identification of the human spirit under the pressure of a seemingly mechanised military existence (the 'herd of life'). Aldington also represents a further category of experience of the war; that of the recognised writer, artist or poet on active service and Aldington here introduces a series of creative men who actually donned uniform at some stage (not always willingly) and fought at the front.

Chapters 2-4 have examined the importance to some individuals, both male and female, of experiencing the war at closer quarters in order to enable them to grasp more accurately intimate knowledge of the conflict, unavailable from second-hand sources (especially the jingoist elements of the British press); a knowledge which could back-up their individual humanistic and aesthetic antiwar emotions and, in some cases, be used to inform their art. The American poet Harriet Monroe, reviewing Richard Aldington's poetry collection Reverie in 1918 wrote that:

The poet accepts war, as he might accept a cyclone, in anguish and bitterness of spirit but without revolt. He feels no élan, no conviction of war's necessity or righteousness, but he takes his place in the ranks and does his part with a grim and resolute stoicism. And out of his despair, out of his hunger for beauty, comes a lyric note clearer and richer than anything we have heard from him since those earliest poems, and an exaltation of spirit as noble and impassioned, and perhaps more humane. ${ }^{1}$

John Galsworthy wrote of the artist's attempts to whisper above the noise and power of a hurricane, and Richard Aldington used a similar analogy in his celebrated novel of the Great War, Death of a Hero, in which the character George (a soldier) describes the war as, 'a sort of impersonal, natural calamity, like a plague or an earthquake'. ${ }^{2}$ Although Death of a Hero did not appear until 1929, Aldington had entered the war with a literary background. By the summer of 1914, he was a published poet and listed as an assistant editor of The Egoist. His first volume of poetry, Images, was published in 1915 as he and his wife, the poet Hilda Doolittle (H.D.), perhaps seeking to distance themselves from the effects of the war, moved from Kensington to the more rural 
Hampstead. This move was followed by another in early 1916 to Devon following the stillbirth of their only child the previous year.

From the earliest months of the war, Aldington had felt almost personally threatened by the existence of the conflict. 'This war is killing us all', he wrote to fellow poet Amy Lowell in December 1914:

the daily waiting, the anxiety, the constant strain is making us all old ... I cannot concentrate my mind for long enough on beautiful things to be able to write good poetry ... For this is the great war, the war of democracy against autocracy, of the individual against the state. ${ }^{3}$

Like Galsworthy and others, Aldington feared for his creative powers and felt, like Thomas Hardy, that for some, the war brought with it an ageing process of startling rapidity: 'We have become middle-aged before our time', Aldington would write to his wife during the final autumn of the war. He had resisted enlisting until May 1916, describing conscription as 'the Sword of Damocles' to his great friend Frank Flint, to whom he also addressed an unpublished poem which ended:

Admire, ye faithless, with what speed

These Christians carry out their creed, With what dexterity they shed

The blood of the unrepented.

Their love is such they needs must show it

And make a conscript of a poet. ${ }^{4}$

Aldington and his friend Carl Fallas became infantry Privates in the Devonshire Regiment and underwent training at Wareham in Dorset. It was then that the contrast between Aldington's former literary life and his new military one struck home. In particular, the months immediately before his enlistment had been filled with literary promise combined with great personal freedom while writing and walking in the Devon countryside. The conflict made him feel isolated in his literary aspirations and appreciation of beauty from 'the great herd of men' as he described the war-mad world to H.D. (echoing Galsworthy's perception). The isolation of the training camp, situated on a coast that he described with a poet's eye as a 'grey, sickly peevish line' reinforced Aldington's own singularity, and he wasted no time in likening the 'wild desolate spot' to its earlier role as a prison camp while expressing sympathy with its former labouring convicts who had been forced to construct what were now the barracks out of large blocks of grey Portland stone.

In December 1916 Aldington was promoted to Lance Corporal and shipped overseas. He spent the first half of 1917 serving on the Lens-La Bassée front digging and repairing trenches whilst trying to adjust to army life. He admitted to his friend John Cournos that he was 'living spiritually on letters' and to Flint that 'I yearn for the dear musty smell of old vellum', while Flint's poems, included with his letters were like 'sprays of fresh lilac'. It was also to Flint that 
Aldington expressed his view of soldiering, acquired through personal experience and explained to Flint as a warning. Aldington described how he 'exploded into hate' for certain individuals:

... those imbeciles who pretend that there is anything fine or ennobling or romantic in soldiering. It is simply dreary routine, dreary endurance, dreary 'heroism' of dying at the word of command! ... Somehow some of us will endure to the end, but what will it all be worth? Don't feel too many scruples at being out of it - you have a certain task ... to keep alive something of the gradually enfeebled tradition of beauty in life which we have received from other times.

This view of the artist as torchbearer of the tradition of beauty was one that Aldington found was different now he was constrained by the actual harshness of military experience. He commented to Flint that he had written only twelve poems since entering the army - hence his bequeathing of the role to the (as yet) unfettered Flint. This awareness of a sense of ebbing beauty in time of war was echoed a few months later in a poem by the young writer Alec Waugh of the Inns of Court OTC and subsequently the Machine Gun Corps. Waugh was also undergoing training and his poem was entitled 'Harrowby Camp':

It is not the dirt or the ugliness

Nor the monotony of life,

But its remembered beauty

That tears the soul with a turning knife. ${ }^{6}$

Though Aldington came to value the comradeship of the fighting unit and appreciate the bravery of his fellow soldiers, he was constantly troubled by this sense of 'remembered beauty' and his inability to make full use of this beauty in his art and life, despite attempts such as his clinging to the job of assistant editor of The Egoist until June 1917. To Flint, Aldington tried to justify his place in the war effort:

So many better men have perished in this foolish contest that I have no ... right to claim a hope for exemption for myself. I am not a suicide. I am a soldier ... It is not easy to die but one makes it easier by renouncing those things which have made life dear.?

Aldington seemed to recognise that it was only through trying to forget Waugh's 'remembered beauty' that one could exist from a position within the war with a clear conscience. Once that position was achieved, one could begin to focus on what one truly felt and wanted to express about the war.

By July 1918, Aldington felt he had found his voice and was writing to Flint on the subject of his new poetry that:

I have spoken of the war more frankly than about any other Englishman - the result is that I could not get my poems published and am in the forefront of the battle. Do you think for an instant that if I had chosen to adopt the official point of view I could not have got a 'cushy job' ... like so many others; Say what you will, I have kept my integrity here and when you read 'Images of War' I think you will admit that I have by implication written a denunciation of the war. ${ }^{8}$ 
Aldington believed that anyone who read his volume of poems with careful attention would be able to discern 'the indignation, the pity, the anguish underneath' and he placed great faith in the total sincerity of his verse.

By this time Flint himself was in training for military service, having been called up in December 1917, a matter of days after Aldington received his commission. When Aldington learned that Flint was to enter the army he commented that, as a sensitive and quickly-wounded poet, Flint might in some way benefit from the depravities and melancholic aspects of the war in terms of artistic material, 'as they have benefitted me'. He warned that although it would seem as if Flint's friends from his former life had forgotten him, there existed a 'spiritual gain' to the suffering of army life within the 'hard relief' of the experience of war. Courage would be forthcoming, and Aldington counselled his friend to seize the opportunity 'in the gaps of liberty allowed you' and to 'grasp at life with a zest you never before had'. ${ }^{9}$ This advice contained the truth of Aldington's own reaction to the army, but, in reality, one side of Aldington hoped Flint would avoid the entire experience and a few months later, in his letter just cited concerning his latest poems (Images of War), Aldington stated, 'I do hope you escape the army ... how on earth will you endure the stern, insulting discipline'.

The truth of Aldington's words lay in the 'hard relief' of experience of the war and the possible spiritual gain to the individual which lay therein. By retaining his 'integrity' in the army and an ability to 'grasp at life' in moments of relief, Aldington had found he was better able to communicate a message of truth from the 'cockpit of suffering', a phrase used by the writer John Cowper Powys to describe a war that he thought wicked and absurd. Yet, although Powys described his attitude to the war as 'natural' or as 'feminine ... and therefore singularly close to nature', he also believed that it was more noble to take part than to stand on the sidelines. Although the war was a 'fiery furnace', he made several attempts to join up (though he was almost forty and was rejected on medical grounds) because, as he later explained, 'Persons of spirit hurried to get as close to the flames as they could'. ${ }^{10}$

This attitude towards experience of the war was held by another medically unfit writer, John Middleton Murry who was called up in 1916, classed as unfit for active service (B2) and found himself working for the War Office. To him, the war was 'a pure nightmare, an interruption of some strange and inhuman order of existence'. During Aldington's 'gaps of liberty', when, as Murry later described, 'I was in some sense myself', Murry tried to ignore the war because, 'anything that I could call myself and the war could not co-exist in my consciousness' ${ }^{11}$ Like Aldington, Murry struggled to keep his integrity and was eventually able to turn 'the face of my consciousness towards the war' and achieve a 'true ecstasy'. He found then that, 'Insensibly, inevitably, every faculty of mine was now strained upon the war ... the thing engulfed me'. Also like Aldington, and to some extent Powys, he found a logic in the conviction that, 
'one must face the war completely, in imagination and consciousness, to the end; that one must behold it until something happened to the sight, until one was blinded, or one saw'. ${ }^{12}$

Aldington himself - attempting to see - found (and admitted to his wife) that, 'my mind is fired with all this turmoil', though he feared, as he wrote in the same letter, that he would be creatively blinded; 'a kind of mental apathy has seized me and my brain refuses to work'. ${ }^{13}$ Amid the 'general futility of things' Aldington's creativity was a dwindling commodity, and he was unsure as to which direction he should apply his remaining 'superfluous energies' - in the invention of stories and tales for his comrades or in poetry. Despite his advice to Flint, in the army he had found a lack of his precious 'gaps of liberty'. 'One must have time to live', he complained to H.D., 'All writing is distasteful if one is without leisure'.

As he entered the final year of the war, Aldington's hope was that though he had found himself emotionally and creatively handicapped by this 'abrupt withdrawal from the rapid current of my life into something alien and painful', he hoped that the experience would be a salutary one. The war and his military life represented a 'pause in my intellectual life', and he was unsure whether this would be the 'final pause' or simply a hiatus preceding 'intense creation'. After receiving his commission in late 1917 and further periods of training at Newhaven and Tunbridge Wells, Aldington returned to France in April 1918 and soon complained in letters to H.D. that he could find no purpose to life at the front, or indeed, life in general and was haunted by an intense loneliness tinged with horror and regret. His attempts to be witty and contemptuous of 'ordinary' people failed because he found himself 'choked and stifled' by thoughts of the dead and the misery of the living.

Though Aldington admitted that there still existed a few of his 'gaps of liberty', there was also 'constant wear' to the mind and body compounded by, similar to Waugh's 'remembered beauty', a recognition of 'having lost somehow the pearl and essence of life'. He described to his wife how he now had:

a precise sensation that what [Robert] Browning would call the 'poetry of life' is over ... the flash has gone from the gun, the perfume from the flower, the ecstasy from music - I shall never live again in the old intense way, never be thrilled by beauty as before ... never live again. ${ }^{14}$

Aldington, in mourning for his old life, also recognised (and again made use of Browning as a reference) that he had been altered by the war:

I have changed, through misery, through routine, through the strain of things. Perhaps I may get back my equilibrium, some sort of life, even write again but 'never glad confident morning again'. One acquiesces in the death of a flower but it is hard to admit that the flower of one's unique life dies as surely and nearly as quickly as the summer lilac. ${ }^{15}$ 
Aldington felt reduced to the level of 'little fruitless gesticulations of existence' and only the letters of friends and the consolations of nature enabled him to appreciate what remained of aesthetic life. At rest and away from the line, he described how the sky ceased to be 'a sinister sneering sort of thing' and instead was transformed into part of the 'great plan' of the natural world, the alternations of seedtime and harvest which embodied the 'spirit of the earth'. He wrote with delight to Flint of how, when lazing in some grass, he had communed with a fieldmouse and to his wife of how her letter allowed him to be part once more of 'that world of ideas which is my world'. He also confided to her, with a combination of relief and fear, that, 'I have found a little of my soul that was lost. Very likely I shall lose it again up in that damnable landscape of war, that wrecked earth which is a blasphemy, an insult to the gods. ${ }^{16}$

Aldington's wife, being a poet herself, was able to empathise with her husband's artistic predicament. During the final months of the war H.D. described her husband as, 'a queer, tortured soul. He has a soul, that is why he suffered. ${ }^{17}$ Aldington was above all concerned with the preservation of his 'soul', his creative facility which was under threat from the hostile emotional and physical landscapes of the war and would be necessary if he were ever to write with clarity on the horror and sadness of his experiences. 'To live according to one's character', he wrote, 'to live against the world's way - isn't that to save one's soul?'18

Gerald Brenan was another fledgling writer in uniform who, like Aldington, felt his soul threatened by the strictures of war. Though his father had obtained a commission for him in the 5th Gloucesters, Brenan found the long evenings in the officers' mess to be destructive of his 'inner life' and hence rented a private sitting-room in which to read undisturbed. By his twenty-first birthday in April 1915 he was at the front, and he spent most of the remainder of that year as part of the Cyclist's Company digging trenches, usually at night, after which Brenan would often be found writing poetry or reading Flaubert until dawn. Although he repeatedly volunteered for one-man reconnaissance missions behind enemy lines and also for the Flying Corps, he was rejected each time and spent most of the rest of the war in observation posts, from which he was able to observe the clumsy terror of the Battle of the Somme and the mocking, featureless plain near his next post on the left-hand side of the Ypres salient. To relieve the tedium he went for long walks and read voraciously: Tolstoy, Gibbon, the Brontës and the Bible. Like Aldington's 'gaps of liberty', these were characterised as creative periods, when 'the fire' was 'alive'. At other times he worried over the fact that, 'I have ceased to be able to read poetry'. ${ }^{19}$

In March 1917 Brenan was moved to an observation post within two miles of Ypres itself in preparation for the summer offensive, and he found himself acting as a guide to senior staff officers due to his expert knowledge of the trench systems. However, he did not see action until June 1918, due to a shrapnel injury sustained almost a year earlier which necessitated a lengthy period of 
convalescence. During his first action, Brenan was again wounded and then shipped back to Scotland to recover from Spanish flu after being awarded the $\mathrm{MC}$ and Croix de Guerre.

It is clear that, despite his misgivings about the war and military life, in common with Aldington and others, Brenan sought the experience: 'I could only burn up the impurities in my nature and become a real and authentic person if I sought them', he later wrote, 'Now in the middle of the war, a life in the infantry offered me much the same opportunities' ${ }^{20} \mathrm{He}$ considered declaring his anti-war views and submitting to a court martial but opted like Aldington for the military experience and, like Aldington, suffered greatly from the isolation and boredom that those of an aesthetic outlook generally underwent. In common with Galsworthy, Aldington's character George (from Death of a Hero) and others, Brenan viewed the war metaphorically at times as a kind of upheaval or interruption of nature; a volcanic eruption in Brenan's case. At other times, when he saw the war as brought about and sustained solely by human intentions, it truly horrified him. Despite this, when he learnt that he was to be sent back to France after recovering from his shrapnel injury, he found himself pleased. This was due in part to his dislike of the 'hatred and hysteria' generated by the popular press and 'old men' at home but also because like many others he found himself drawn to the flames described by John Cowper Powys or, as Brenan called it, 'the Demon' - the spirit of the front line which seemed to offer the only real life to be had during that period. As he wrote in a letter of August 1918:

The Infantry means almost everything that I most dislike and it represents, to my emotions at least, death. But at any rate one is in the full flood; all that there is of life in this generation is there - at the war or else in prison ... this war is no interlude, it is a large part of one's life. ${ }^{21}$

Unlike Gerald Brenan, though they felt alike on war's negative aspects, the poet Max Plowman did (as we have seen in the Introduction) declare his antiwar position and suffer a court martial. Although Plowman enlisted with a view to becoming a member of the London Mounted Brigade of the Royal Field Ambulance (he ended up in the 4th Field Ambulance), he explained to his brother that he thought the war:

a bloody mess and how anybody can want to be mixed up in it beats me. No man properly alive ever kills another whether by machinery or bayonet so that war demands the grossest and foulest insensitiveness on the part of all who have to do with it - it's an infernal soul-searching job and you're damnably well out of it. ${ }^{22}$

Once training had begun, Plowman found that everything was reduced to 'a matter of obedience and routine', and he came to perceive through his own experience how when an individual became part of the war effort, 'he forfeits his self-consciousness and becomes a tiny piece of machinery', and later, in his 1918 pamphlet, The Right to Live, Plowman would describe the war as the 'diabolical slavery of man by a vast inhuman machine'. ${ }^{23}$ 
This loss of self-consciousness led to Plowman becoming, as he put it, 'dulled to the value of life', both to life in general and his own personal interaction with normal existence - this to such an extent that he found he could suddenly, 'put my head into the cannon's mouth or make mincemeat out of a man in a different coloured uniform' ${ }^{24}$ Plowman struggled with the tension that existed between his dislike of the war and taking part in it and his recognition that it could be right to fight, 'until force is proved an idiocy'. To his friend, the author Hugh de Selincourt, he attempted to rationalise his position:

Who am I that I should say to another man - You do my killing? I do not yield my principles one iota because I live in a world that does not acknowledge them and am compelled by circumstances to action I would not voluntarily undertake ... I know we have to make our individual consciences into National ones but everyday we suffer something which may remind us of the disparity between individual and communal conscience and we do it without much murmuring ... we don't make our individual conscience law by refusing to recognise our responsibility for and towards national conscience. ${ }^{25}$

Plowman felt that if he had 'preached peace and internationalism' in the period before the conflict this might have given him the moral authority to have declared himself a conscientious objector upon the outbreak of war. Now, however, he felt that he could not reject national responsibility in favour of that of a personal nature when he had taken previous advantage of the rewards of prewar collective national responsibility ('when the system of things one has prospered under has led inevitably to war'). Experience of war was to enable him to make a choice between public and personal demands. Plowman felt that if it was not for his experience of the military side of the inferno, he would have no right to profess his anti-war views and would have little sympathy with the 'absolutist' conscientious objectors. 'And so I'm here', he wrote to de Selincourt in October 1916:

in mud and blood and all the damned insanity of war and I wouldn't be out of it, things being as they are, for I can seen no alternative, things being as they were - I know that gradually the individual ideal must permeate the national, but till then how can I, after benefiting by all the nation's virtues, disclaim all personal responsibility for its sins? And what moment shall I choose to protest my individuality?26

Almost a year later, Plowman informed de Selincourt that he had begun experiencing what he called 'the pressure of life'. Although he felt that in the army (and thus in the war) the human spirit was confined to a position where it only 'conglomerates and coagulates', Plowman had become aware of and attracted to a latent internal creative force representing 'infinite beauty' which he felt was ever present and waiting only for recognition, 'to become fruitful in us of all we most desire'. The 'pressure of life' resulting from the war was now preventing Plowman and, he recognised, others of a similar nature from utilising this potential energy for creative or peaceful effect. He was in effect being drawn to a similar concept to that of Bertrand Russell and the ideas contained in 
Russell's Principles of Social Reconstruction concerning the latent creativity within most human beings which could act as a deflection from the destructive impulses that led to war. It was time for Plowman to protest his individuality.

In January 1918 he wrote to the Adjutant of the 52nd Durham Light Infantry that, 'organised warfare of any kind is always organised murder', ${ }^{27}$ and proffered his resignation from the army. He was at first arrested for refusing to obey an order and placed in near solitary confinement but his mind was made up; 'What I believe is most urgent now', he wrote to his sympathetic correspondent Janet Upcott, 'is that we should explore the recesses of individual consciousness to discover the ultimate basis of individual freedom' - this in order to find a 'new alchemy' for freedom on a national level. As he saw it, an individual's choice was now clear - to fight in the front line trenches or to fight against organisation for war. In order to fight against the war, one could obtain a 'harmless' war job and then, 'expend all your best energy in practical peace politics', or as Russell had suggested, 'the best work in the world - that artistic work which weans men's and women's minds and hearts and bodies from the perversion of war'. ${ }^{28}$ This 'creative praise of life' was, in any case, for Plowman the only natural way of living. When it came to his own choice, Plowman felt that, as he had supported the war machine by fighting, his only option was just as obviously to fight against it by 'getting into prison for peace'.

Despite a trial and appeal, Plowman was sent a call-up notice at the start of July 1918 and became tangled in a web of bureaucracy between the two government departments of Registration and Appeals. He was in danger of being sent to prison as a deserter and not as a conscientious objector, which moved Plowman to comment on the grim irony of a situation which he felt was a, 'complete inversion of all natural order', and the organisation of which he felt to be 'literally anti-life'. Despite his ignominious position, Plowman clung to his belief that, "participation in war is an individual matter, and the fact that a man is given an individual mind and an individual body and not a national mind and body is proof to my mind that he will be held responsible for the use or misuse he puts that mind or body to'. ${ }^{29}$ In War and the Creative Impulse, the book he wrote on finally leaving the army, Plowman described the choice that the war had imposed; between the 'appeal of individual consciousness' and 'national consciousness which made the denial of individual consciousness the first duty'. The war was a 'vandal', deliberately slashing at the 'great canvas whereon the spirit of life has found expression', and, specifically citing Bertrand Russell's conceptual example, Plowman called for the reconstruction of society upon a creative basis in order to be able to call forth the 'final passions war now filches for destructive purposes'. ${ }^{30}$

For Plowman and others, the experience of being within the war machine acted both as a compass toward and a justification of his later anti-war stance. Two further examples of this process concerned possibly the most celebrated poets of the war - Siegfried Sassoon and Wilfred Owen. Sassoon has much in 
common with Plowman: both were rated good officers, both possessed an acute sympathy towards their men and both resigned their commissions as a protest against the war.

In December 1915 the country-loving Sassoon, newly arrived in France as an officer with the 1st Royal Welch Fusiliers, ${ }^{31}$ wrote that his immediate experience was that of a 'waking dream' and that, 'my inner life is far more real than the hideous realism of this land of the war zone ... I want a genuine taste of the horrors, and then - peace'. Like Plowman, he felt a sense of obligation on a wider level than that of individual motivation to take some part in the war; his military training had 'unsealed' his eyes and although he had been forced to make sacrifices, he felt that he had lived rather too well since his enlistment; 'now I ask that the price be required of me. I must pay my debt.. ${ }^{32}$ Sassoon had initially enlisted as early as 3 August 1914 and some of his war poems from The Old Huntsman (1917) date from the period during his officer-training before he went to France in late 1915. In one of his earliest 'war poems', 'Absolution' - placed first in his War Poems - Sassoon touched upon a fundamental paradox of war;

War is our scourge; yet war has made us wise, And, fighting for our freedom, we are free. ${ }^{33}$

Wilfred Owen on the other hand was more wary of the experience of war and it was not until 21 October 1915 (just as Sassoon was preparing for embarkation), that he visited the headquarters of the Artists' Rifles off London's Euston Road and allowed himself to be examined and passed fit for military service. As Sassoon was enlisting in August 1914, Owen had been staying at Bagnères-deBigorre in the Pyrenees and had actually returned to London as late as May 1915 and then gone back to France the following month, still unsure of his future. At one point he was taken up with the idea of joining the Italian cavalry, though this possible course of action was prevented by the fears of his mother. A further option, that of a sightseeing trip to the Near East, was prevented by the prolongation of the Dardanelles campaign. 'I don't want the bore of training', he wrote to his mother after his return to France in June 1915, 'I don't want to wear khaki; nor yet save my honour before inquisitive grand-children fifty years hence. But I do most intensely want to fight. ${ }^{34}$

Although Owen felt almost a 'mania' to see the fighting, as he believed that the conflict would be 'the last War of the World', he was concurrently 'furious with chagrin to think that the Minds which were to have excelled the Civilisation of ten thousand years are being annihilated'. After observing the many wounded French and German soldiers who began to arrive in Bagnères, he began to conceive the notion that his individual poetic fight was worth protecting; 'my life is worth more than my death to Englishmen', he wrote, commenting that his motivation towards survival on a battlefield would be, 'the sense that I was perpetuating the language in which Keats ... wrote'. ${ }^{35}$ In this Owen was unconsciously echoing Richard Aldington's view of the soldier-artist having a duty to 
keep alive something of 'the gradually enfeebled tradition of beauty in life'. Touching upon the familiar theme of the need for greater experience of the conflict, Owen felt that he could not compare the life of the trenches to his own of creativity, 'unless I felt in a manner to have suffered my share of life', ${ }^{36}$ and it was during this period, February and March 1915, that Owen was wavering over whether the experience of the war would inform or harm his creative existence. To him the 'fullest life liveable' was that of a poet; it was, 'the one title I prize, one clear call audible, one Sphere where I may influence for Truth, one workshop whence I may sound forth Beauty, one mode of living entirely congenial to $\mathrm{me}^{\text {' }}$. $^{7}$

Sassoon also placed high value on his role as an artist (being a soldier-poet had 'complex advantages', he recalled in his memoir Siegfried's Journey); after less than a month in France in December 1915, he wrote in his diary, 'Wish the Kaiser would let me go back to my work at writing poems'. Although the military life was 'mechanical', Sassoon was able to draw inspiration and hope from his inner life; 'The Angel is still there, Poetry, with bright wings prepared for flights into the dawn'. He also drew strength from nature and the countryside, both remembered (from England) and actual (behind the lines in France). However, the desolation of the natural world at the front had the opposite effect. In Flanders, the sky, instead of being a reminder of the freedom contained within nature, was merely a 'death-haunted appendage' to a land altered by the conflict of human beings. Above the reflected battlefields the sky had lost its former, 'bird-held supremacy of whiteness and clarity'.

Sassoon's first taste of the front line was from March to April 1916, and he was determined to utilise the experience of a life he found 'audacious and invincible' (at least until it was, 'whirled away in enigmatic helplessness and ruin'). ${ }^{38}$ His aim was to collect 'as many sensations as possible ${ }^{39}$ in order to replace the lost 'music and graciousness of life' and fill up an existence of 'naked outlines and bare expanses, so empty of colour and fragrance'..$^{40}$ Nevertheless, he was greatly relieved to leave this period of 'mechanical and strained effort' at the end of April and to find the countryside behind the lines acknowledging the arrival of spring. After training at Flixécourt, Sassoon saw action at the front line in May and for his 'conscious gallantry during a raid on the enemy's trenches' he was awarded the MC the following month.

Despite periods of inner calm and a certain relish for the heightened emotions of battle, he still felt that there was 'no music; the quest for beauty [was] doomed', and he admitted to his diary in July that unless one attempted to place one's viewpoint from a position outside events, 'this life begets a life of mental stagnation ... I try to see everything with different eyes to my companions, but their unreasoning mechanical outlook is difficult to avoid' ${ }^{41} \mathrm{He}$ was temporarily removed from his troubling surroundings, however, by an attack of trench fever which saw him awarded sick leave until December 1916. 
Sassoon's period of leave marked a further shift in attitude towards the war and the necessities thereof. Whereas previously death in battle had possessed the possibility of attaining nobility, now, however, following the possibly delayed emotional impact of the deaths of Sassoon's brother Hamo on 1 November 1915 (of wounds incurred in the Dardenelles) and his beloved soldier friend David Thomas on 18 March 1916, as well as the start of his involvement with Lady Ottoline Morrell and the pacifists, the very thought of death was 'horrible' and his MC was merely an 'absurd decoration'. In his diary he quoted H.G. Wells's troubled Mr Britling - 'It is a war without a point, a war that has lost its soul' - and resolved to 'get a grip on the idea of life and describing it', while hoping (unlike during the previous year) that he would not meet his end in 1917 as 'there's such a lot to say'.

Sassoon was now almost ruthless in his desire to record the true bleakness of the war; 'there is little tenderness left in me', he wrote in February 1917, 'only bitter resentment and a morbid desire to measure the whole ignominy which men are brought to'. He recorded how the soldiers he observed made him feel that, 'there is no hope for the race of men'. Like Bertrand Russell, he saw the potential for good within individuals being smothered by the conflict; 'all that is wise and tender in them is hidden by the obsession of war'. The soldier, to Sassoon, was, 'no longer a noble figure; he is merely a writhing insect among this ghastly folly of destruction', and he feared that, 'the agony of armies will be on every breeze; their blood will stain the flowers', while, worst of all, 'the foulness of battle will cut off all kindliness from the hearts of men'. Sassoon noted how, as soon as men were relieved of responsibility via the army machine, they became 'bovine' and mere 'beasts of burden' ${ }^{42}$ Although he recognised that the soldiers he observed were, 'not their own masters in any way', he found himself 'drawn back into the Machine' as if the responsibility for his own life had been taken from him.

Enveloped by a mood of 'unreasoning acquiescence', Sassoon took part in the spring offensive of April 1917 (the Battle of Arras) and was wounded in the shoulder. He was invalided back to England, and his book of poems The Old Huntsman was published in May and reviewed appreciatively by Thomas Hardy, Arnold Bennett, Virginia Woolf and by H.W. Massingham in the Nation. The collection was also praised by Sassoon's friend and fellow 'C' Company officer Julian Dadd, who was recovering after having been shot in the throat. Dadd (to whom one of the poems in The Old Huntsman was dedicated and who had previously described his friend as 'an artist who really tries to see and write the truth') wrote to Sassoon declaring that the published poems were 'absolutely first rate' and adding that, 'I only hope the majority of people will similarly appreciate the greater truth of your point of view'. ${ }^{43}$ It was during May 1917 that Sassoon decided to make his celebrated 'A Soldier's Declaration'. A diary entry from that month reveals that he now perceived his only option, other than a return to the 2 nd Battalion and the front was, 'some protest against the 
war', and with the help of Bertrand Russell, the Declaration was drafted in June, sent to his Commanding Officer on 6th July, read out in the House of Commons on 30 July and published in The Times the following day.

During the drafting of the statement (as well as during the months previously), Sassoon had read Russell's On Justice in War-Time and entered into correspondence with its author. Sassoon wrote to the academic on 23 June, providing an insight into his view of the war and the motivations which had led to his decision to protest publicly:

People say to me 'Nothing can stop the war till some glimmering of the truth dawns on the Prussian junkers' - They never ask themselves how long it would take 'the truth' to dawn on them if someone was going for them with a loaded stick. I suppose 'the truth' is the infallibility of the British point of view. Sometimes I feel that any appeal to the human element is hopeless - War seems to reduce all that to futility. Fifteen-inch shells are the only things that carry any conviction with them. And the soldiers are gulled into concealing their loathing of the war by the civilians who only half-disguise their own liking for it. ${ }^{44}$

In common with Max Plowman, Sassoon felt an obligation towards a wider sphere than his personal motivations. However, whereas in Sassoon's case it was his need to proclaim his case that led to his earlier and more public protest, with Plowman, it was the wider responsibility that held his personal feelings in check for so long until he could restrain them no longer. Commenting on the proposed Declaration, Middleton Murry had written to Ottoline Morrell in June counselling caution, stating that an act of insubordination or deliberate martyrdom made on the spur of the moment and without consultation, 'could make no substantial impression against the gigantic evil of the war'. ${ }^{45}$ Though Lady Ottoline found the eventual Declaration to be 'extraordinarily good', others more eminent in the literary world were not so enthusiastic: Edward Marsh thought Sassoon to be 'intellectually wrong', Robbie Ross was 'appalled' (though this sprang from a concern for Sassoon's personal safety) and Arnold Bennett thought the intentions behind the Declaration 'misguided'. According to him, Sassoon should have come out against all wars or 'declared for anarchy', and Bennett accused him of 'spiritual pride' coupled with an indulgence in a right 'to which you are not entitled'. ${ }^{46}$

From others the response was more positive; in his post-war critique Reputations, Douglas Goldring pointed out that Sassoon's verses had, he thought, found especial favour with his fellow soldiers as well as with 'the more human and imaginative sections of the English public' ${ }^{97}$ Sassoon's friend and Quartermaster of the 1st Battalion, Joe Cottrell, wrote to him warmly, stating, 'I hope trouble doesn't strike you for sailing too near the wind - telling the truth' and followed this up with a further letter in which he declared that, 'I admire you for your standing out and for having the courage of your convictions ... War is hideous and no one knows it more than you and I ... One dare not think of this war - if so - we should go mad. ${ }^{48}$ Cottrill was unsure of the timing of Sassoon's 
Declaration and feared that Sassoon would be court martialled. He had showed Sassoon's letter (presumably containing details of his protest) to two of his fellow soldiers and reported to Sassoon that, while not so sure of the 'opportuneness' of the action, 'they, like me, admire your motives'. In 1929, Sassoon received a letter from his friend Julian Dadd who recalled that summer of 1917 and how, 'We were badly worried at the idea that you were getting yourself into serious trouble with the army authorities in your anxiety to stop a needless war'. Dadd remembered that, 'It was a horrible time, but I do not think you have any cause to regret that. You had a bit of a Bertrand Russell in you as well as a V.C. ${ }^{49}$

Sassoon had already been sent to Craiglockhart War Hospital by a medical board by the time his Declaration was read out to the Commons on $30 \mathrm{July} .{ }^{50} \mathrm{~A}$ postcard from H.G. Wells in September counselled patience:

Don't get locked up and out of the way. Then don't do anything exceptive. Do ostentatiously sober things. Take your discharge for 'shock'. Then let any action show that it was a mere excuse, that you are a grave and balanced man set upon the peace of the world. Don't develop into a 'case'. Treat all that happens to you as incidental to the effort of sane men to get this crazy world into a state of order again. Don't seem to become in any way a man with a grievance. If sensitive fine minds allow themselves to be tormented into mere shrieks of protest then the blockheads and blood dunkers will prevail for ever.

Wells concluded that Sassoon and himself were 'in the same line'. ${ }^{51}$

Sassoon decided that he wanted to be passed fit for general service in order to 'share the ills' of the individuals on whose behalf he had made his protest, and he felt that to remain under medical supervision or to be discharged as medically unfit for service would cripple the validity of both his anti-war stance and his resulting war poetry. Similarly, he rejected Ottoline Morrell's plan to 'make a commotion' after leaving Craiglockhart and being passed fit for service. The authorities, he felt, would merely label it a relapse in his condition and shut him away again, perhaps this time for the duration of the war.

Consequently, Sassoon rejoined the Royal Welch Fusiliers at Litherland in December 1917 and spent March and April in the Middle East with the 25th Battalion. Army life was now a mixture of 'crude circumstance' and an inner 'flame-like' spiritual experience. He had now, he thought, acquired a degree of self-realisation and found himself free to study other people and events shaped by the war with an intense scrutiny; 'equipped to interpret this strangest of all my adventures - ready to create brilliant pictures of sunlight and shadow'. ${ }^{52} \mathrm{He}$ now felt he was 'getting outside it all' (in contrast to his previous intense personal involvement whilst on active duty) and while he felt he was approaching the 'secret places of the heart' he also recognised its 'piteous limitations', concluding that, 'I recognise the futility of war more than ever, and, dimly I see the human weakness that makes it possible. ${ }^{53}$ 
Sassoon also recognised the incompatibility between the life of the spirit and that of a life curtailed by martial rules. He had taken an enormous amount of literature with him to Palestine, including Keats, Wordsworth, Hardy, Browning, Trollope, Bunyan, Scott and Plato, and had taken up his reading once more, after a period of training, on his return to France; 'The result is that I immediately lose my grip on soldiering and begin to find everything intolerable except my interest in the humanity of the men. One cannot be a good soldier and a good poet at the same time. ${ }^{54}$ Sassoon's friend Julian Dadd had earlier commented on Sassoon's character - that he supposed it, 'not reasonable to expect anyone to combine the characteristics of a poet and champion bomber with the constitution and nervous system of a horse'. ${ }^{55}$

However, the soldier-poet chose to return to the 'soul-deadening' theatre of war - a war in which there was, 'no time for emotion, no place for beauty. Only grimness and cruelty and remorse. ${ }^{56}$ On his subsequent return to France with the 25th Royal Welch Fusiliers, Sassoon felt a desire 'to share its terrors' in order to 'learn yet more the meaning of it - and the effect'. At the same time, he felt it was 'inconceivable' that he was returning to assist in the destruction of human life. Sassoon reached the front line as 'acting' Captain of 'A' Company in July and almost immediately was again wounded (mistaken for a German and shot in the head by one of his own men) and shipped back to England where he would remain for the remainder of the war.

In the month before he was wounded for the final time, Sassoon's second volume of poetry, Counter-Attack, was published. It contained many of Sassoon's now celebrated poems describing in stark detail the war's harsh reality and was widely praised. Max Plowman in the Labour Leader declared that Sassoon had 'told the truth' about the war and even the normally jingoistic Morning Post described Sassoon as 'a poet of power and precision' who, having 'served gallantly' at the front had thus earned the right 'to enter a minority report'. ${ }^{57}$

On reading Counter-Attack, Sassoon's fellow soldier and hunting enthusiast, Geoffrey Harbord, of the Royal Field Artillery, wrote to him exclaiming, 'You poor devil. I never realised 'till I read them how much more some people feel the horrors and bloodiness of it all than I do.' For Harbord, some of the poems struck a raw nerve; 'Counter-Attack is damn good', he admitted, but he added that, 'it conjures up the smell of dead and mud and that horrible pit of the stomach feeling too vividly'. However, this vividness was necessary for an audience that had not experienced the realities of trench warfare. 'I only hope', wrote Harbord, whose brother Gordon (a regular soldier in the Artillery since 1912 and Sassoon's long-term friend) had been killed the previous month, 'that the people at home get the same feelings out of the book that I do. It must bring it home to them more than anything else they have ever or will ever read. ${ }^{58}$

It was Sassoon who had encouraged Wilfred Owen to increasingly include and describe the vivid realities of trench warfare in his poetry as part of a more complete and truthful emotional response to the war, a response that Sassoon 
felt and Owen recognised had perhaps been hitherto lacking. The two famously met at Craiglockhart in the summer of 1917, with Owen having arrived there about a month before Sassoon. The meeting would be a turning point in Owen's war, just as his first experience of the front had been in January of the same year (after fourteen months of training). That he described as 'seventh hell', having spent several hours in a water-filled dug-out. To Owen's poetic eye, No Man's Land had resembled a body 'pock-marked' with disease and even under snow it was like the face of the moon, 'chaotic, crater-ridden, uninhabitable ... the abode of madness'. Owen admitted that, although he could to some extent endure the cold, fatigue and 'face-to-face death', an extra node of suffering for him was 'the universal pervasion of ugliness ... everything unnatural, broken, blasted'. ${ }^{59}$ Life at the front was, 'the eternal place of gnashing of teeth'.

Owen was given time to reflect of his first taste of the 'real' war as he spent two months out of the line in February and March 1917, due to his attendance of a course for transport officers and then due to injury, having fallen into a ruined cellar. During this period of reflection Owen, like Gerald Brenan, attempted to contain the suffering of the present within hopes for the future. While Brenan expressed a desire to live in a cottage in Spain, ${ }^{60}$ Owen's cottage was to be in rural Kent or Sussex with an orchard with pigs to tend. Owen also commented to his sister that when he had looked into the future on his twentyfirst birthday, he had not seen the war coming. 'But if I had', he added, 'I should certainly have borrowed sixpence and bundled over into Spain.' Owen confessed this in May 1917 after almost being buried alive during action with the 2nd Manchesters in the vicinity of Savy Wood during the previous month, an incident which, together with his other front-line experiences since January, caused Owen to suffer a return of psychological problems that had plagued him during 1912/13. He was observed behaving strangely, examined by a psychologist and sent to Craiglockhart.

It was during and after his treatment at Craiglockhart and the commencement of his friendship with Sassoon that Owen began to produce his most celebrated poetry of war. We read that Owen's meeting with Sassoon was regarded by Owen as quietly momentous ('At last ... an event worth a letter') and that simply reading Sassoon's poems sent Owen to a 'high pitch of emotion'. After getting to know Sassoon, Owen's assessment of his friend as 'simply honest about the war' bore out his original assessment of Sassoon's work, made during the period before they met, that, 'nothing like his trench-life sketches has even been written'. ${ }^{61}$ Though Sassoon was the more experienced in terms of both military action and poetical expression, there were similarities in both that each responded to; Owen recognised that, 'we have followed parallel trenches all our lives'. Though Adrian Caesar in his Taking it Like a Man has written that, 'there were aspects of the war that both found exciting, stimulating and emotionally fulfilling ... this gave rise to massive guilt feelings', Caesar also comments that both were drawn to suffering and death in war in an attempt 
to assuage their additional guilt over their suppressed homoerotic feelings. However, to say that their protests against the conflict were also an attempt to assuage the overall guilt of attraction to war and made on behalf of 'inarticulate' comrades (and perhaps isolated fellow homosexuals) is to overstate the case. One could surely appreciate the comradeship and loyalties of war while being appalled by its effects.

Owen's time at Craiglockhart helped him to refine his anti-war stance in response to his initial but severe military experience and his desire to develop his poetical output in line with Sassoon's advice and his own growing awareness of what the war meant to him both as an individual and in terms of the future possibilities of mankind. Although he compared himself to a satellite spinning in orbit around the blazing nova of Sassoon himself, it was now time for Owen to 'swing out' and become his own 'dark star'. As he wrote to his mother, 'The tugs have left me; I feel the great swelling of the open sea taking my galleon. ${ }^{63}$ Both poets decided to return to the war.

After leaving Craiglockhart in October 1917, Owen was granted leave and then posted to Scarborough followed by Ripon, in March 1918. He was eventually passed fit for general service in June and returned to France in August. It was during the final period of his life, after his meeting with Sassoon at Craiglockhart and eventual return to service with a renewed confidence in his role as a communicator of the true nature of war and its effects on the men it touched, that Owen wrote the poems for which he is most celebrated, such as 'Dulce Et Decorum Est', 'Insensibility' and 'Strange Meeting'. He famously wrote to his mother on the last day of 1917 that he left that year as a poet, 'as which I did not enter it', and he described the particular 'incomprehensible look' of the men in France 'which as man will never see in England ... it was more terrible than terror, for it was a blindfold look, and without expression, like a dead rabbit's. It will never be painted, and no actor will ever seize it', he continued, concluding that, 'And to describe it, I think I must go back and be with them. ${ }^{64}$ It was necessary to return to the heart of the war in order to convey its stark truths with dignity as well as revulsion, even if this meant being a part of the army machine once more, or as Owen described the transformation, becoming a 'cattle-driver', a 'Herdsman' and, worst of all, a 'Shepherd of sheep that do not know my voice'. For his part in the military action during the weeks before his death on 4th November, Owen, like Sassoon before him, was awarded the Military Cross. The fighting had been so intense that the experience of it had passed beyond Owen's sensibilities; as he reported to Sassoon, 'it passed the limits of my Abhorrence. I lost all my earthly faculties and fought like an angel. ${ }^{65}$

Owen's reaction would have been recognised and appreciated by another famous poet of the Great War, Robert Graves (of the Royal Welch Fusiliers). Graves was adept at smothering over his oscillating private reactions to the war with the routine of military duty and expectation. While agreeing with the 
humanistic motivations behind Sassoon's Declaration - Sassoon was 'quite right in his views but absolutely wrong in his action', as he wrote to Edward Marsh ${ }^{66}$ - Graves believed at the same time that it showed gross 'bad form' and disloyalty to fellow men in uniform, especially those in the Regiment. Graves (who in the same letter to Marsh described himself as a 'pacifist in thought' even though he viewed himself as a 'sound militarist' in deed) was swift to reassure Sassoon at Craiglockhart that, 'of course you're sane. The only trouble is you're too sane which is as great a crime as being dotty and much more difficult to deal with. That's the meaning of an anti-war complex. You see what other folk don't see about the rights and wrongs of the show', concluding that, 'Personally I think you see too much.'

Graves's concern was with the outward effect of an anti-war protest on the very individuals ('the Bobbies and Tommies and so on') that Sassoon was supposedly trying to influence. According to Graves and his belief in military form, these were the people who would be most affronted by any action similar to Sassoon's, which would be regarded as 'bad form'. This in Graves's eyes was 'the worst accusation' possible between friends and comrades-in-arms. The only way to command respect was to share the miseries of the war and, he told Sassoon, to 'finish your contract whatever it costs you' while denouncing the principles behind the conflict, though presumably in a more private way than a statement in the Commons and publication in The Times. Thus Sassoon would then be able to do more good both now (though in a subtler form) and after the war and although Graves acknowledged that his friend had 'done your bit', he added (with more than a hint of accusation) that he himself believed in 'giving everything' ${ }^{67}$

Though both Sassoon and Graves (and Wilfred Owen) were in agreement by this stage on the need to return to the war, their motivations were different; Graves thought a return to the front was necessary because he believed in 'keeping to agreements' and 'biding my time' until such time as a 'sporting chance' occurred to alter the state of affairs. Sassoon, on the other hand, believed a return to the war necessary to validate the sentiments expressed in his Declaration and, in common with Owen, those appearing in his poetry of the war. It is notable that amongst the poems concerning the war within Graves's own Fairies and Fusiliers, which was published in December 1917, there is little protest against the conflict, only sentiments of regret and sadness at the loss of comrades coupled with a respect for the regiment and its traditions.

Ironically in view of his advice, Graves by this time (the late autumn of 1917) had become permanently unfit for service at the front having completed four consecutive tours of duty, during one of which he had been famously left for dead. He had become an instructor in an officer cadet Battalion based firstly at Wadham College, Oxford and then, after treatment for his nerves, at Rhyl with the 3rd Battalion. While Graves was getting married and preparing for a more domestic existence, Sassoon was training on a gas course in Ireland in 
anticipation of further active service in Palestine. Now Graves wrote to Sassoon that the contrast between them made him feel 'ashamed', though he admitted he was glad his friend was being sent to Palestine because there was less likelihood of Sassoon being fatally injured. Graves had decided that to finish one's 'contract' whatever the cost was no longer as desirable as previously; 'I'm most awfully keen on your living', he admitted to Sassoon, in order that his fellow poet, with rested nerves, would be able to produce 'miraculous poetry' ${ }^{68}$ Graves's concept of a poet, as he outlined it to his fellow poet in uniform Robert Nichols, was one who appreciated both the refinements of life (through the splendours of Nature and close friendships) together with its harshness and hence the process of being a poet was comparable to a woman suffering the hardships of a man and thus 'hardening her weak softnesses'. ${ }^{69}$

In his loyalty to his regiment, desire for the experience of combat, horror of 'bad form' and general restless enthusiasm, Graves could be seen to be attempting to harden his 'weak softnesses', and in a letter to his literary mentor Edward Marsh of February 1916, Graves had acknowledged a 'hardening and coarsening and loss of music' within his verse which he readily attributed to 'la guerre'. In reality, Graves, though always by his own admission a 'sound militarist in action', possessed underlying pacifist notions ('a pacifist in thought') coupled to a realistic view of the hatreds that fanned the flames of the conflict. He agreed with Sassoon's Declaration in that he also thought 'our people' should state definite peace terms to bring a swifter end to the misery and, on a more personal level, he was not above praising some of Sassoon's most anti-war poems, such as 'To Any Dead Officer', for which he suggested amendments in June 1917 (the summer of the Declaration), some of which Sassoon had adopted by the time of its appearance in Counter-Attack the following year. 'In theory the War ought to stop tomorrow if not sooner', Graves declared to Edward Marsh, 'Actually we'll have to go on while a rat or a dog remains to be enlisted. ${ }^{70}$ Graves was trapped by his own character within the army machine. He had earlier written to Marsh and admitted that, 'I have to live up to my part here as I have learned to worship my Regiment: in sheer self-defence I had to find something to idealise. ${ }^{71}$

Graves's external need to idealise was born of his inner desperation. His worship of his regiment began to wane after experience of the Somme. The focus of idealisation then perhaps shifted to the military bravery of his (internally anti-war) fellow soldier-poets, who in their military experience exemplified Graves's external regard for honouring 'the contract' while publicly or privately they might express the anti-war views that Graves carried within him and with which he felt a need to empathise. Sassoon, with his bravery both on the battlefield and the moral front, became an object of private idealisation (as he did with Owen), despite Graves's public disapproval of the Declaration. 
I send you here my two latest poems, which I have managed to write, though in utmost distress of mind, or perhaps because of it. Believe me, the army is the most detestable invention on this earth and nobody but a private in the army knows what it is to be a slave. ${ }^{72}$

So wrote Isaac Rosenberg in March 1916 while training with the 11th King's Own Royal Lancasters at Aldershot. He came from a background far removed from that of most of the other 'War Poets' - that of the Jewish East End of London - and despite enlisting voluntarily, declared to Edward Marsh that, 'I never joined the army from patriotic reasons', concluding, 'Nothing can justify war'. However, in common with Owen, Sassoon and others discussed in this chapter, Rosenberg recognised the need for direct experience of the war to be able to produce the poetry that could convey its truth to others not involved in the fighting, and inspire the sympathy of recognition in those that did participate at the front line. Hence his acknowledgement that his latest poems were perhaps due to the 'distress of mind' produced by his circumstances.

In common with Wilfred Owen, Rosenberg had been abroad during the first few months of the conflict and, like Owen, had taken his time in deciding to join up. Both Owen and Rosenberg valued their roles as artists extremely highly and were unsure at first of the effect of war experience on their artistic ability. Rosenberg, who painted as well as wrote, observed from Cape Town how Europe had stepped into its 'bath of blood' and imagined himself waiting until the war was over, 'with beautiful drying towels of painted canvas and precious ointments to smear and heal the soul; and lovely music and poems'. ${ }^{73} \mathrm{He}$ also felt that the world had been 'terribly damaged' in that poets and artists were being sacrificed in 'this stupid business' and felt keenly, as he had told Marsh, 'the immorality of joining up with no patriotic convictions'. However, in October 1915 and under financial pressure ('There is certainly a temptation to join when you are making no money', he had told Ezra Pound), Rosenberg enlisted at Whitehall, 'though it is against all my principles of justice', as he described to Sydney Schiff, his artistic patron. ${ }^{74} \mathrm{He}$ therefore requested service with the Medical Corps but was rejected due to his height and accepted instead into a 'Bantam' battalion, part of the new 40th Division in which the regulation height had been reduced. To Rosenberg, enlisting was 'the most criminal thing a man can do', ${ }^{75}$ and he soon suffered under the harsh reality of life at the Bury St Edmunds Depot. When offered a promotion to Lance Corporal ${ }^{76}$ he declined and by June 1916 he found himself in France.

Gerald Brenan wrote that while his poetry and reading ability were adversely affected by the war, he also felt a 'desire to suffer', recognising that the experience could be ultimately beneficial in understanding the conflict and his part in it. ${ }^{77}$ Similarly, Rosenberg explained to fellow poet Lawrence Binyon that despite his being (like Brenan), 'cramped intellectually' by the war, he was determined that it: 
... with all its powers of devastation, shall not master my poeting; that is, if I am lucky enough to come through all right. I will not leave a corner of my consciousness covered up, but saturate myself with the strange and extraordinary new conditions of this life, and it will all refine itself into poetry later on. ${ }^{78}$

However, Rosenberg's death on 1 April 1918 in the German attack on the British 3rd and 5th Armies near the centre of the Western Front put paid to any chance of future artistic refinement, and the final few months of Rosenberg's life had witnessed his artistic hopes declining: 'there is no chance whatever for exclusion or any hope of writing poetry now', he wrote in February 1918. 'Sometimes I give way and am appalled at the devastation this life seems to have made in my nature', he admitted, 'It seems to have blunted me'. He added in a later letter that, 'we will become like mummies - look warm and life-like, but a touch and we crumble to pieces', an apposite metaphor for the perceived sapping of creative capacity. ${ }^{79}$ This was a remarkably similar reaction to that of another soldier-poet, Edmund Blunden, who in June 1917 at Ypres described the war as, 'a sort of slow poison ... that keeps on drugging and deadening my mind', adding that he loathed war and the army life. He had found that, 'literature languishes as a whole in the battalion ... some of us are mummies, only we still carry on the motion of breathing, swathed round with red-tape and monotony, ${ }^{80}$

From the first, Blunden had been 'not anxious to go', as he recalled at the very start of his memoir Undertones of War which, like his poetry, is filled with pastoral images warped by the malign pressure of the war upon the landscape. Like Sassoon, Blunden had been brought up in the rural tranquillity of Kent and shared his passion for the countryside and the natural world. The devastation of France, therefore, made a great impression on him which reflected itself in his later poetry and recollections, in particular Blunden's realisation of the reality of what the war meant and its overshadowing of all else. Rosenberg felt he had been 'blunted' by the war; Blunden, a young countryman experiencing modern war, found his 'sensibility blurred' by the 'general grossness' of the front and the landscape so deadened that to even speak would be 'an act of creation'. ${ }^{81}$

Despite his revulsion of war, Blunden's attitude could be said to resemble that of Graves more than most other major poets of the conflict. Blunden enlisted in 1914 (though did not enter the army until the summer of 1915 due to his Oxford scholarship) and though, unlike Graves, he was more prolific in his poetic output with three volumes published by 1916 (the year he went to France), he kept the realities of soldiering and the writing of poetry as separate as possible. His biographer described him as 'a pastoral poet in a war setting', ${ }^{82}$ while Blunden referred to himself in Undertones of War as a 'harmless young shepherd in a soldier's coat'. In the midst of intense and bloody activity on the Somme and at Thiepval Wood in 1916, which would result in Blunden being awarded the Military Cross for his reconnaissance missions, he was congratulated 
by his colonel on a positive review given to a volume of Blunden's poems reviewed in the Times Literary Supplement - a volume which, significantly, was entitled Pastorals. Blunden eventually spent two years in the firing line, more than Rosenberg, Sassoon (whose poems he discovered in the Cambridge Magazine) and even Graves.

Although Blunden, as he wrote privately in 1917, 'loathed' the war and the military machine, he fought his way through it and, like Graves, only really found himself able to publicly express his deeper feelings in the years following the conflict. Hence he was only later able to equate the 'ghostly gallows-trees' of Thiepval Wood with the 'ruins of the world ... black and unalterable' in Undertones of War, which was first published in 1928. It is also significant that he entitled a selection of his Poems 1914-30 (which appeared in 1930) as, 'War: Impacts and Delayed Action'. The passage of time enabled Blunden to question publicly the meaning of the war and, in the light of his own long experience of the front line, he was able to ask:

Is it nearer the soul of war to adjust armies in coloured inks on vast maps at Montreaul or Whitehall, to hear of or to project colossal shocks in a sort of mathematical symbol, than to rub knees with some poor jaw-dropped resting sentry, under the dripping rubber sheet, balanced on the greasy fire-step, a fragment of some rural newspaper of $\mathrm{Mr}$ [Horatio] Bottomley's oracle beside him ${ }^{83}$

It was time for Blunden to point out, as he did in his introduction to a 1930 Anthology of War Poems, that the world in which figures such as Sassoon, Owen, Graves and himself had come to 'maturity of thought' had been a world which for that crucial period of time had, 'rolled the individuals into one red burial'. ${ }^{84}$ It was now time for him to question even his own experience, as he did when he wrote of the aftermath of the fighting in late 1916 around Thiepval Wood and the Schwaben Redoubt for The Listener in 1929:

After this winter battle we left the Somme - but who were we? Not those who had marched South in the time of ripening orchards; a very different body of men. We had been passed through the furnace and the quicksand ... There is no escape from the answer given on 1st July to the question of the human race. ${ }^{85}$

During September 1914, D.H. Lawrence, critically perceptive as always, had written to his friend, barrister Gordon Campbell, of his disappointment in watching the majority of mankind make war on itself. They - his fellow human beings - were 'vulgar fools' who could always be expected to make a noise, 'because they are afraid of the silence'. Lawrence stated that those who deliberately made war deserved their fate; however, he also admitted himself to be very concerned for, 'those who, being sensitive, will receive such a blow from the ghastliness and mechanical, dissolute, hideous stupidity of war that they will be crippled beings' ${ }^{86}$ Lawrence was here, perhaps unknowingly, describing himself and his own reaction to the war, but there were others, as we have seen, of 
the type he feared for. The soldier-poet Ivor Gurney is perhaps a supreme example of a sensitive individual transformed into a 'crippled being' by his experience of the conflict. In particular, Gurney's musical background (at the Royal College of Music, under composers Hubert Parry and Charles Standford) little prepared him for the bleakness of war.

The summer of 1914 had found the naturally solitary Gurney walking the countryside of his native Gloucestershire. However, he initially found the prospect of immersing himself in the war to be of possible artistic value, and he volunteered for active service as soon as conflict was declared, but was rejected due to his defective eyesight. However, a second attempt to enlist in February 1915 was successful, and he was drafted into the 2nd/5th Gloucesters. After training at Park House Camp on Salisbury Plain, he was sent to France in May 1916 from where he wrote to his friend Marion Scott that, 'it would be hard indeed to be deprived of all this artist's material now' ${ }^{87}$ However, in the same letter he quoted Shakespeare's Sonnet 129: 'The expense of spirit is a waste of shame/Is lust in action ...' and described how time out of the company had allowed him to breathe 'the air of freedom almost forgotten'. For one such as himself ('who so much desires freedom') - he recognised that it was painful to dwell too much on the conditions of life at the front and even his initial enthusiasm had been tempered by an inner doubt as to the war's effect on himself. During the period prior to the start of the war Gurney had experienced a stronger need for self-expression and had been made 'cold' with thoughts of the possibility of 'leaving all I have to say unsaid'. ${ }^{88}$ His hope now was to somehow utilise any 'artist's material' available to him at the front.

As he tried to overcome the 'thought-vacuum' of military life, Gurney took comfort in the 'store of poetry and accumulation of pictures' within himself and wrote to his friend, the musician Herbert Howells, that, 'You can imagine, too, what the hope of being able to praise England and make things to honour her is in me, as in yourself', though he also confessed, 'You can imagine too what a conflict there is between that idea and warfare. ${ }^{89} \mathrm{He}$ also admitted to Howells that the most disturbing thought was all his 'continual striving' and endeavours to become 'a fit and full man' could be ended in an instant by a German bullet. He described himself as 'Hamlet in khaki' - as one who was unfit for army life; 'a being cut off from Civilisation by the fixed gulfs of Militarism'. As the date for his embarkation for France drew nearer, he felt as if he had condemned himself to a kind of 'practical blindness and deafness' which was particularly galling to himself as an artist possibly about to face either death or, 'that which might be so fruitful to him'.

Once in France in June 1916, the full horror of the war displayed itself to Gurney, a man yearning only for the chance for artistic expression. He immediately wrote home that the life was, 'an awful life for an artist', ${ }^{90}$ and that he felt that the only chance for him to be a good soldier was if he could forget music and books as, 'a sense of beauty is every hindrance to a soldier'. ${ }^{91}$ As the autumn 
of that year gave way to winter and Gurney's regiment went southwards to Albert in order to join the final days of General Haig's Somme offensive, he was still desperately hoping that his experience would be of some use to him from an artistic point of view, and he attempted to rationalise that it was:

better to live a grey life in mud and danger, so long as one uses it ... as a means to an end. Someday all this experience may be crystallised and glorified in me; and men shall learn by chance fragments in a string quartet or a symphony, what thoughts haunted the minds of men who watched the darkness grimly in desolate places. ${ }^{92}$

However, the pain of existence in the front line (where Gurney found himself in December 1916) was so great for him that he admitted to Marion Scott that, 'for myself it sometimes comes that death would be preferable to such a life'. ${ }^{93}$

During the harsh winter of early 1917 and a corresponding month's training at Gapennes, Gurney recognised that he had made a conscious decision to be a musician and artist rather than a soldier and hence 'I suffer in proportion to my sensibility'. Despite this, he felt that he could not fully understand the war from a position that was 'right out of it'. His role as a soldier gave him 'a right to talk and walk with braver men than myself and an insight into thousands of characters and a greater Power over Life, and more Love' ${ }^{94}$ As the Germans withdrew to the Hindenburg Line during the spring of 1917, the Gloucesters followed them, and Gurney was wounded on Good Friday and sent to hospital in Rouen. From his hospital bed, Gurney, like Wilfred Owen and Gerald Brenan, expressed a desire for a simpler, peaceful life wherein he could return to being the creative artist he once was; 'Oh for a garden to dig in, and music and books in a house of one's own, set in a little valley from whose ridges one may see Malverns and the Welsh hills, the plain of the Severn and the Severn Sea; to know oneself free there from the drill-sergeant and the pack and to order one's life years ahead'. ${ }^{95}$

In the midst of the war, and, as we have seen, in common with others, Gurney felt his artistic awareness to be waning. He described how he had reached a state where he knew from an objective point of view how good a Shakespeare sonnet was but was unable to 'wrap myself up in it' nor 'dwell on the lines to taste their sweetness'. His soul was now, as he described it, 'sick with disgust', and Marion Scott's letters (as Frank Flint's letters and poems had been 'sprays of fresh lilac' to Richard Aldington), were like 'promises of blue' to Gurney, who longed for peace and beauty of the remembered countryside of home. Life itself, without his music, books and friends, lacked the 'vital impulse and natural joy' of his former existence.

By this time (the summer of 1917), Gurney was fighting in the Third Battle of Ypres and in September was gassed at St Julien and sent back to England. He admitted that his experience of the war had created 'a great gap in my mind' which he should now fill up with 'sunsets, trees, winds, stars and children's faces', all of which he found to be, 'blossoming fairer after so long a drought'. To musician Herbert Howells, he described himself on his return from France as 'frosted up' and after a few days rest he felt 'the beginning of the thaw, the 
first hint of what joy music might give'. ${ }^{96}$ Gurney's first volume of poetry, Severn and Somme, was published during this period, in October 1917 (to be followed by War's Embers in 1919).

Despite the beginning of a possible 'thaw' within himself, Gurney spent the following few months in and out of hospital, a period which culminated in a breakdown, following further training, in March 1918. He spent the remainder of the war in hospital, coming close to suicide at times. Eventually he was sent home to Gloucester in October 1918 and although he returned to London in an attempt to resurrect his musical compositional training (this time with Vaughan Williams as his tutor), it proved too much for him and by 1922 he was declared insane and committed to the City of London Mental Hospital where he lived until his death in 1937. Ironically, he had in a sense predicted this, when in September 1917 on his return from France he wrote that, 'War brings greater selfcontrol - or breakdown. You must also have mastery of yourself, or perish. ${ }^{97}$

The ordeal of Ivor Gurney exemplifies the reaction to the war of celebrated writers who donned uniform at some stage during the conflict and thus were presented with direct experience of the war. We have seen in the cases of Sassoon, Owen and Gurney in particular, though opposed in practical or aesthetic terms to the war, the conflict could act as a magnet to some individuals, exerting an initial creative pull on their imaginations. As a poet, Sassoon hoped to collect 'as many sensations as possible' when on active service, ${ }^{98}$ while Owen felt that his creative potential would not be fulfilled unless, as he put it, he had, 'suffered my share of life', and Gurney felt a need to utilise all the 'artist's materials' on offer in order to make his voice heard.

Harriet Monroe, reviewing the war poems of Richard Aldington, described the artist's view of the war as that of an individual to a cyclone: with anguish but also stoicism in the face of inevitability. Out of the artist's 'hunger for beauty' and despair, hoped Monroe, a clear 'lyric note' might emerge. The experience of the artist or poet at the front could be crucial if the individual was to find this true voice in regard to the conflict - Sassoon's desire to collect sensations was transformed into 'a morbid desire to measure the whole ignominy which men are brought to', and Owen, though he admitted that the war had made him a poet, was appalled at the prospect of having to return to the front - a place 'of the gnashing of teeth' and only returned after his time at Craiglockhart in order to describe the 'blindfold look' of his fellow men - the level to which humanity had been degraded.

Ultimately, as in the case of Ivor Gurney, the war could impose a gradual stifling of creativity upon artistic individuals - an effect which was more severe if those individuals actually fought and observed the war's effects close up. Gerald Brenan found that not only was he unable to be continually creative at the front, he was less able to absorb the fruits of artistic endeavour - in his case he found himself at times unable to read poetry. This chapter examines how individuals with creative potential resented and felt trapped and then coarsened 
by the unthinking organisational apparatus of a military existence. Max Plowman recognised that an individual, once part of the war effort, forfeited his selfconscience and became 'a tiny piece of machinery'. Isaac Rosenberg felt he had been 'blunted' by his experience of the war, and Edmund Blunden found his 'sensibility blurred' by his long period of service at the front. We have seen these concerns shared by writers and artists who did not fight - the concern of Bloomsbury for the civilised values of art and culture mirrors Owen and Rosenberg's chagrin over the potential annihilation of the creative minds who were to have carried forward the 'Civilisation of ten thousand years', for example. It is easier, however, to hold these articulate thoughts up to the light of re-examination, as they are so well-expressed and the products of minds that have made their influence felt (whether intentionally or not) through the succeeding generations. But what of the similar thoughts and feelings of those whose shadows across history are perhaps paler and not as lengthy?

\section{Notes}

1 Harriet Moore in Poetry, vol. 12, no. 1, April 1918, cited in Richard Aldington and H.D. The Early Years in Letters, ed. C. Zilboorg (Bloomington, IN, 1992), p.75.

2 Richard Aldington, Death of a Hero, Authorised unexpurgated edition, limited edition of 300 copies (2 vols, Paris, 1930), vol. 2, p. 38.

3 Richard Aldington to Amy Lowell, 7 Dec. 1914, Aldington, Early Years, pp. 20-1.

4 University of Victoria, British Columbia, Canada. Doyle Collection (UV,DC hereafter). Photocopies of correspondence between Richard Aldington and F.S. Flint (originals held at Henry Ransom Humanities Research Centre, University of Texas at Austin). Aldington to Flint, 12 June 1916.

5 UV,DC, R. Aldington to Frank Flint, undated (Nov./Dec. 1916).

6 Alec Waugh, Resentment (London, 1917), p. 44.

7 UV,DC, R. Aldington to F. Flint, undated (Autumn, 1916).

8 Ibid., 7 July 1918.

9 Ibid., 28 Dec. 1917.

10 John Cowper Powys, Autobiography (London 1934), p. 583.

11 John Middleton Murry, Between Two Worlds (London 1935), p. 338.

12 Ibid., pp. 432-3.

13 R. Aldington to H.D., 23 July 1918, Aldington, Early Years, p. 112.

14 Ibid., 8 Sept. 1918.

15 Ibid., 1 June 1918. The quote is from Robert Browning's 'The Lost Leader' (1845).

16 Ibid., 16 July 1916, p. 108.

17 Cited in Charles Doyle, Richard Aldington-A Biography (London, 1989), p. 64.

18 R. Aldington to H.D., 24 July 1918, Aldington, Early Years, p. 113.

19 Cited in J. Gathorne Hardy, The Interior Castle (London, 1992), p. 117.

20 Ibid., cited p. 127.

21 Gerald Brenan to Hope, 18 Aug. 1918 in Brenan, A Life of One's Own, (London, 1975), p. 235.

22 Max Plowman to his brother, 3 Jan. 1915, Bridge into the Future: The Letters of Max Plowman, ed. D.L. Plowman (London, 1944) p. 29.

23 Max Plowman, The Right to Live (London, 1918), p. 10. Plowman was also the author of a celebrated memoir, A Subaltern on the Somme, originally published under the pseudonym 
'Mark VII', (London, 1927).

24 Bridge into the Future, ed. Plowman, M. Plowman to Janet Upcott, 29 Jan. 1915, p. 32.

25 Ibid., M. Plowman to Hugh de Selincourt, undated, pp. 36-7.

26 Ibid., M. Plowman to Hugh de Selincourt, 18 Oct. 1916, p. 57.

27 Ibid., M. Plowman to Adjunct, 14 Jan. 1918, p. 92.

28 Ibid., Plowman to Janet Upcott, 28 Feb. 1918, pp. 105-6.

29 Ibid., M. Plowman to Adelaide Hunt, 16 April 1918, p. 117.

30 Max Plowman, War and the Creative Impulse (London 1919), pp. 18, 32, 120.

31 Sassoon originally volunteered as a trooper for the 1st Sussex Yeomanry on 3 August 1914 but later transferred to the Royal Welch Fusiliers and commenced officer-training.

32 Sassoon, 3 Dec. 1915, Siegfried Sassoon -Diaries 1915-1918 , ed. Rupert Hart-Davis (London, 1983), p. 22.

33 Siegfried Sassoon, War Poems (London, 1983), p. 15.

34 Wilfred Owen to Susan Owen, June 1915, The Collected Letters of Wilfred Owen, ed. Harold Owen and John Bell, (Oxford 1967), pp. 340-1.

35 Ibid., W. Owen to S. Owen, 2 Dec. 1914.

36 Ibid., W. Owen to S. Owen, 6 Feb. 1914.

37 Ibid., W. Owen to S. Owen, 5 March 1915, p. 326.

38 Sassoon Diaries, ed. Hart-Davis, 30 March 1916, p. 47.

39 Ibid., 31 March 1916, p. 51.

40 Ibid., 14 April 1916, p. 55.

41 Sassoon Diaries, ed. Hart-Davis, 13 July 1916, p. 92.

42 Ibid., 22 Feb. 1917 and 15 Feb. 1917, pp. 132, 133.

43 Imperial War Museum (IWM hereafter), Sassoon correspondence, P. 444, (Con. shelf), Julian Dadd to S. Sassoon, 12 May 1917.

44 The same letter contained a re-worded section of the proposed Declaration for Russell's inspection as well as Sassoon's earlier version on the same sheet, with a question mark next to it, which had been corrected by Russell and returned. Both versions contained the proposition that if the purposes of entering the war had been clearly stated at the outset, it would have been impossible to alter them without the knowledge of the soldiers. The original draft then stated that if this was the case, 'the war would now be at an end', while the new version, following Russell's amendments, read, 'had this been done, the objects which actuated us would now be attainable by negotiation'.McM,BRP, Sassoon to Russell, 710.055469, 23 June 1917 (and containing 710.055479).

Sassoon's letters during these crucial weeks also reveal that there existed at one stage a plan to publish the Declaration as a leaflet. They also exhibit Sassoon's opinion towards the reactions of his superiors, once he had sent the Declaration to his Commanding Officer. 'They [his military superiors] are evidently "keeping me in suspense" in the hope that I may become amenable to a chance of backing out', he informed Russell. However, despite a lack of immediate action and an apparent tolerance and 'amiability' from his superiors, Sassoon revealed to Russell that he had informed them that his protest, 'had gone beyond their control or mine', adding that, 'I don't think they understand in the least what it's all about'. By the start of July, Sassoon had overstayed his period of leave by a week and he sent Russell the telegram from 'the Adjt. 3rd Royal Welch' ordering him to 'Join Litherland immediately', with Sassoon himself commenting to Russell, 'we must get the statement published as soon as possible, and all will be over bar the shouting'. Ibid., Sassoon to Russell, 710.055474 and 710.055475, July 1917.

45 McM,BRP Ottoline Morrell to B. Russell, 710.082632, 11 June 1917. Murry's letter was included with Lady Ottoline's to Russell.

46 See Sassoon Diaries, ed. Hart-Davis, pp. 179-81.

47 Douglas Goldring, Reputations (London, 1920), p. 108.

48 IWM, Sassoon correspondence, P. 444, (Con. shelf), Joe Cottrill to S. Sassoon, 29 July 1917 
and 11 July 1917.

49 Ibid., J. Dadd to S. Sassoon, 1 Dec. 1929.

50 Sassoon's account of his time at Craiglockhart, and his relationship with his largely sympathetic doctor, W.H.R. Rivers, can be found in the initial section of his fictionalised memoir Sherston's Progress, which itself forms the concluding part of The Complete Memoirs of George Sherston (London, 1937). Craiglockhart becomes Slateford War Hospital. Sassoon's meeting and subsequent friendship with Wilfred Owen is covered in Chapter 6 of the 'factual' Siegfried's Journey (London, 1946).

51 McMaster University, Hamilton, Ontario, Canada, William Ready Division of Archives and Research Collection, H.G. Wells Archive, Wells to Sassoon, postcard (Sept. 1917).

52 Sassoon Diaries, ed. Hart-Davis, 14 Feb. 1918, pp. 212-13.

53 Ibid., 17 April 1918 and 23 April 1918, pp. 235, 238.

54 Ibid., 15 June 1918, p. 271.

55 IWM, Sassoon correspondence, P. 444, (Con. shelf), J. Dadd to S. Sassoon, 29 March 1917.

56 Sassoon Diaries, ed. Hart-Davis, 15 June 1918, p. 271.

57 The Morning Post, 2 Aug. 1915, cited in Jean Moorcroft Wilson, Siegfried Sassoon - The Making of a War Poet: A Biography (1886-1918) (London, 1998), p. 496. A notably bad review was, surprisingly, that of John Middleton Murry in the Nation, though Murry's main criticism was that it was the war and the state of the world thereof that had caused Sassoon to react in the way he had (as an 'instrument of discord ... so jangling').

58 IWM, Sassoon correspondence, P. 444, (Con. Shelf), Geoffrey Harbord (14th Division, Mesopotamia Expeditionary Force) to S. Sassoon, 9 Sept. 1918.

59 W. Owen to S. Owen, 4 Feb. 1917, Collected Letters of Owen, ed. Owen and Bell, p. 431.

60 Ibid., W. Owen to Mary Owen, 25 May 1917, p. 464.

61 Ibid., W. Owen to S. Owen, 12 Sep. 1917, Collected Letters of Owen, ed. Owen and Bell, pp. 493-4.

62 Adrian Caesar, Taking it Like a Man: Suffering, Sexuality and the War Poets (Manchester, 1993), p. 151.

63 W. Owen to S. Owen, 31 Dec. 1917, Collected Letters of Owen, ed. Owen and Bell, p. 521.

64 Ibid.

65 Ibid., W. Owen to S. Sassoon, 1 Sept. 1918, p. 580.

66 Robert Graves to Edward Marsh, 12 July 1917, In Broken Images - Selected Letters of Robert Graves, ed. Paul O'Prey (London, 1982), p. 77.

67 Ibid., R. Graves to S. Sassoon, 27 Oct. 1917, p. 85.

68 Ibid., R. Graves to S. Sassoon, 6 Feb. 1918, p. 92.

69 Ibid., R. Graves to Robert Nichols, 2 Feb. 1917, p. 65.

70 Ibid., R. Graves to E. Marsh, 12 July 1917, p. 77.

71 Ibid., R. Graves to E. Marsh, 9 Feb. 1916, p. 39. Graves had a great admiration for the soldier-poet Charles Hamilton Sorley, having been impressed by the deceased Sorley's Marlborough and Other Poems ('so entirely after my own heart in his loves and hates'). Both were the same age and had attended Oxford University (Graves at St John's College; Sorley at University College). Sorley had been killed near Loos in October 1915 whilst serving as a temporary Captain in the 7th Suffolks. Although he had enlisted, Sorley had found the military life one of 'routinal coma' and he complained of, 'a large amount of organized disorderliness, killing the spirit. A vagueness and dullness everywhere'. His fear was that he would become 'non-individual and British'. See Jean Moorcroft Wilson, Charles Hamilton Sorley (London, 1985), p. 191.

72 Isaac Rosenberg to Lascelles Abercrombie, 11 March 1916, Isaac Rosenberg - Collected Works and Letters, ed. Ian Parsons (London, 1984), p. 231.

$73 \mathrm{Ibid}$., I. Rosenberg to E. Marsh, (Oct.Nov. 1914), p. 206.

74 Ibid., I. Rosenberg to Sydney Schiff, 8 June 1915, p. 216.

75 Ibid., I. Rosenberg to Sydney Schiff, 8 June, 1915, p. 216. 
76 See Joseph Cohen, Journey to the Trenches -The Life of Isaac Rosenberg (London, 1975), p. 130.

77 Gathorne-Hardy, Interior Castle, p. 117.

78 I. Rosenberg to L. Binyon, (autumn 1916), Rosenberg - Collected Works, ed. Parsons, pp. 248-9.

79 Ibid., I. Rosenberg to Miss Seaton, 14 Feb. 1918 and 8 March 1918, pp. 268, 270.

80 Edmund Blunden, 22 June 1917 cited in Barry Webb, Edmund Blunden - A Biography (London, 1990), p. 73.

81 E. Blunden, Undertones of War, (Oxford, 1956), pp. 270, 202. Blunden's memoir was first published in 1928.

In his poem 'Zero', Blunden finds that the beauty of the dawn in the trenches brings no consolation; 'What is the artist's joy to me?' the narrator asks, when, 'Here limps poor Jock with a gash in the poll/His red blood now is the blood I see'. Edmund Blunden, 'Zero', cited in John Silkin, Out of Battle: The Poetry of the Great War (London, 1987), p. 109. Originally in Blunden's Poems 1914-30 (London, 1930) from the section entitled 'War: Impacts and Delayed Actions'.

82 Webb, Blunden, p. 50.

83 Blunden, Undertones, p. 230. Horatio Bottomley was a notoriously jingoistic writer, journalist and self-publicist.

84 E. Blunden, Introduction to Anthology of War Poems, ed. Frederick Brereton (London, 1930), p. 23.

85 E. Blunden, 'The Somme Still Flows', The Listener, 10 July 1929 and reprinted 18 Jan. 1979, p. 100.

86 D.H. Lawrence to Gordon Campbell, 21 Sept. 1914, The Collected Letters of D.H. Lawrence, vol. 1, ed. Harry T. Moore (London, 1962), pp. 290-1.

87 Ivor Gurney to Marion Scott, 7 June 1916, The Collected Letters of Ivor Gurney, ed. R.K.R. Thornton (Manchester, 1991), p. 87.

88 I. Gurney to M. Scott, 16 June 1914, cited in Michael Hurd, The Ordeal of Ivor Gurney (Oxford, 1978), p. 54.

89 I. Gurney to Herbert Howells (Oct. 1915), Collected Letters of Gurney, vol. 1, ed. Thornton, p. 52.

90 Ibid., I. Gurney to Mrs Voynich (June 1916), p. 90.

91 Ibid., I. Gurney to M. Scott, 21 June 1916, p. 102.

92 Ibid., I. Gurney to M. Scott, 9 Dec. 1916, p. 171.

93 I. Gurney to M. Scott, 7 Dec. 1916, cited in Hurd, Ordeal of Ivor Gurney, p. 86.

94 Ibid., I. Gurney to M. Scott, 18 Jan. 1917, p. 191.

95 Ibid.,I. Gurney to M. Scott, 11 May 1917, p. 78.

96 Ibid., Gurney to Herbert Howells, 2 Oct. 1917, p. 111.

97 I. Gurney to M. Scott, 26 Sept. 1917, Collected Letters of Gurney, vol. 1, ed. Thornton, p. 332 .

98 Sassoon hoped this 'for the sake of poetry and poets whom I represent'. Sassoon, 31 March 1916, Sassoon Diaries, ed. Hart-Davis, p. 51. The assimilation of sensations could be an aesthetic activity in itself - see Paul Levy, The Case of Walter Pater (London, 1978) and David Newsome, The Victorian World Picture (London, 1997) which both discuss Victorian cultural aestheticism. 